LASSEN, N.A. (1966) The luxury perfusion syndrome and its possible relation to acute metabolic acidosis localized in the brain. Lancet, ii, 1113.

MCGARRY, J.D. \& FosTER, D.W. (1972) Regulation of ketogenesis and clinical aspects of the ketotic state. Metabolism, 21, 471.

Ohman, J.L., Marliss, E.B., Aoki, T.D., Munichoodappa, S., Khanna, V. \& KozaK, G.P. (1971) The cerebrospinal fluid in diabetic ketoacidosis. New England Journal of Medicine, 284, 283.

OpIE, L.H., Kadas, T. \& Gevers, W. (1963) Effect of pH on the function and glucose metabolism of the heart. Lancet, ii, 551 .

Posner, J.B., Swanson, A.G. \& Plum, F. (1965) Acid base balance in cerebrospinal fluid. Archives of Neurology, 12, 479.

PoSNer, J.B. \& Plum, F. (1967) Spinal fluid pH and neurological symptoms in systemic acidosis. New England Journal of Medicine, 277, 605.
Soler, N.G., Bennett, M.A., Fitzgerald, M.G. \& Malins, J.M. (1972) Potassium balance during treatment of diabetic ketoacidosis with special reference to the use of bicarbonate. Lancet, ii, 665.

Soler, N.G., Bennett, M.A., Fitzgerald, M.G. \& Malins, J.M. (1973) Intensive care in the management of diabetic ketoacidosis. Lancet, i, 951.

STEWART, J.S.S. (1964) Management of cardiac arrest, with special reference to metabolic acidosis. British Medical Journal, 1, 476.

Walker, B.G., Phear, D.N. \& Martin, F.J.R. (1963) Inhibition of insulin by acidosis. Lancet, ii, 964 .

Young, E. \& Bradley, R.F. (1967) Cerebral oedema with irreversible coma in diabetic ketoacidosis. New England Journal of Medicine, 276, 665.

Zimmet, P.Z., TAFT, P. \& ENNis, G.C. (1970) Acid production in diabetic acidosis: a more rational approach to treatment. British Medical Journal, 3, 610

\title{
Diabetes insipidus and marked elevation of foetal haemoglobin in a case of acute leukaemia
}

\author{
W. J. K. Cumming* \\ B.Sc., M.B., B.Ch.

\section{Summary} \\ A case of acute myelomonocytic leukaemia is described \\ in which diabetes insipidus was the presenting symptom.
}

A. S. D. SPIERS

M.B., Ph.D., M.R.A.C.P.

Department of Haematology, The Royal Postgraduate Medical School, Du Cane Road, London

\section{Case report}

A 46-year-old man first presented in Iran, in October 1972, with a history of polyuria, anorexia and fever for 2 weeks. He had lost $18 \mathrm{~kg}$ weight in the preceding year. On examination he was found to be anaemic ( $\mathrm{Hb} 6.5 \mathrm{~g}$ ), with hepatomegaly of $3-4 \mathrm{~cm}$ and a 'palpable' spleen. The urinary specific gravity was 1.002 . Bone marrow at that time showed 'many abnormal cells'. A diagnosis was made of diabetes insipidus secondary to a malignant process and he was treated with 5 i.u. vasopressin tannate nocte with considerable improvement in the polyuria. This was subsequently changed to nasal pitressin t.d.s. in view of increasing pain at injection sites. He was transfused with three units of whole blood and transferred to Hammersmith Hospital for further investigation.

When first seen on 21 November 1972 he was found to have a $\mathrm{Hb}$ of $7.8 \mathrm{~g}$, WCC $3000(30 \%$

\footnotetext{
* Present address: Department of Medicine, Newcastle General Hospital, Newcastle upon Tyne.
}

neutrophils, $20 \%$ blasts, $33 \%$ lymphocytes, mono- $\stackrel{\mathbb{D}}{\triangle}$ cytes $9 \%$ and eosinophils $8 \%$ ) and platelets 192,000 . $\overrightarrow{\overrightarrow{0}}$ Bone marrow showed acute myelomonocytic leu- $\frac{3}{3}$ kaemia. Alkali denaturation showed $47 \%$ resistant $\bar{Z}$ $\mathrm{Hb} ; \mathrm{Hb}$ A2 estimation was $1.2 \%$ and electrophoresis showed an $\mathrm{Hb} \mathrm{A} / \mathrm{F}$ pattern. The patient was therefore admitted for further investigation.

During the first week in hospital the nasal pitressin was stopped, and his mean urinary output was $61 / 3$ day, average SG 1000 and average osmolality $1 \cdot 05$, and 260 for urine and plasma respectively. Detailed investigation of his hypothalamic-pituitary-adrenal 응 function was carried out. A poor response to intra- $\supset$ venous thyroid-releasing hormone was obtained, the 음. TSH values at 0,20 and $60 \mathrm{~min}$ following injection $\overline{\mathrm{N}}$ being $1.6,2.5$ and $2.8 \mu / \mathrm{ml}$ respectively. There was $\sigma$ a normal basal level of luteinizing hormone and $\tilde{N}$ follicular stimulating hormone and following intra- N venous thyroid-releasing hormone was obtained, the $\sigma$ TSH values at 0,20 and $60 \mathrm{~min}$ following injection 0 being $1.6,2.5$ and $2.8 \mu / \mathrm{ml}$ respectively. There was $\underset{\mathcal{D}}{\overparen{D}}$ being $3 \cdot 8,22 \cdot 0$ and $28 \cdot 0$ respectively. However, $\stackrel{?}{+}$ serum FSH levels measured in $\mathrm{m} \mu / \mathrm{ml}$ were $4.4,5.970$ and 7.6 respectively showing a poor and slow response of follicular-stimulating hormone. This is in keeping with the 'hypothalamic pattern of response' (Hall $\stackrel{\AA}{\AA}$ 
et al., 1972) and is compatible to that response found with thyrotrophin-releasing hormone where the hypothalamic cells responsible for the production of TSH have low values of this hormone owing to preexisting hypothalamic disease. Following an insulin tolerance test there was a normal response of both cortisone and growth hormone. Protein bound iodine was normal at $4.6 \mu \mathrm{g} / 100 \mathrm{ml}$, the normal range in the laboratory being 4-8. Serum T3 was normal at $4 \cdot 9$, the normal range being $4 \cdot 7-8 \cdot 1$ and $\mathrm{T} 4$ was normal $8.5 \mu \mathrm{g} / 100 \mathrm{ml}$, the normal range being $5.4-11.8 \mu \mathrm{g} /$ $100 \mathrm{ml}$. A clomiphene test was normal, the values for luteinizing hormone on the tenth and eleventh days being 7.6 and $7.8 \mathrm{~m} \mu / \mathrm{ml}$ respectively and for testosterone being 286.0 and $295.0 \mathrm{ng} / 100 \mathrm{ml}$ respectively. Urinary output of 17 oxosteroids and 17 oxogenic steroids was normal, being $7.3 \mathrm{mg}$ and $28.9 \mathrm{mg}$ per $24 \mathrm{hr}$ respectively. Eight and $15 \mathrm{hr}$ water deprivation tests were carried out and both confirmed the presence of diabetes insipidus. The values on the $8 \mathrm{hr}$ tests were $U_{3} 90, P_{3} 300 ; U_{3}: P_{3} 0 \cdot 3 . U_{3}$ represents the urine passed in the sixth and seventh hours of the 8 $\mathrm{hr}$ deprivation test and $\mathrm{P}_{3}$ is the plasma sample in the mid-point of that period. In the normal person the urine osmolality should be $600 \mathrm{mosmol} / \mathrm{kg}$ or more and the plasma osmolality should not be greater than 300 . The $U_{3} / P_{3}$ ratio should be greater than 2 in the normal and less than 1.9 in confirmed diabetes insipidus. Following exogenous ADH the patient was able to concentrate his urine normally on an $8 \mathrm{hr}$ water deprivation test. Radiography of the skull and pituitary fossa was normal as were the chest X-ray and intravenous pyelogram. Brain scan was normal. Lumbar puncture showed an increase in monocytoid cells and normal CSF pressure; no leukaemic cells could be identified on a cytocentrifuge preparation.

Treatment was started with chlorpropamide 250 mg b.d. and the patient subsequently had an average urinary output of 2 1/day, SG 1.010 and osmolality of 310 .

In the normal individual, $\mathrm{Hb} \mathrm{F}$ should account for no more than $1 \%$ of the total haemoglobin after the sixth month of life. In this patient the value of presentation was $47 \%$, and haemoglobin electrophoresis showed an $\mathrm{Hb} \mathrm{A}$ and $\mathrm{F}$. The $\mathrm{Hb} \mathrm{A}_{2}$ was reduced, $1.2 \%$. A slight increase in $\mathrm{Hb} F$ has been described previously in acute leukaemia (White, 1972), but to our knowledge the level found in this case has not been previously described. Following transfusion with a total of 7 units of blood, the $\mathrm{Hb} \mathrm{F}$ level fell to $8.8 \%$. There are three possible explanations for the marked increase in Hb F. (1) That the patient had a form of thalassaemia; (2) that he was heterozygous for the High Fetal gene; and (3) that it was a consequence of his leukaemia. The first was excluded by the finding that the relative rates of $\alpha$ and $\beta$ chain synthesis measured in his circulating reticulocytes was 1.03 (normal range $0.95-1 \cdot 1$ ). The second possibility was excluded by finding that the $\mathrm{Hb} \mathrm{F}$ was heterozygously distributed throughout the red cells. We conclude therefore that the $\mathrm{Hb} \mathrm{F}$ was being synthesized by the same abnormal leukaemic clone of stem cells. Chemical analysis of the chain is being undertaken.

Acute myelomonocytic leukaemia was diagnosed on the bone marrow findings which also showed a blast cell content of $70 \%$. Since the patient was found to have a high level of cytidine kinase in the bone marrow cells (Tattersall, 1973) he theoretically should have responded to cytosine arabinoside by infusion. However, his blast cell count was $2900 / \mu l$ before a 24 infusion of cytosine arabinoside and had fallen by only $70 \%$ (to $850 / \mu \mathrm{l}$ ) $48 \mathrm{hr}$ after the infusion was finished. Because of this failure treatment was started with the TRAP regimen $(T=$ thioguanine $100 \mathrm{mg} / \mathrm{m}^{2} /$ day on days $1-5$, p.o. $R=$ rubidomycin $40 \mathrm{mg} / \mathrm{m}^{2}$ on day 1 , i.v. $A=$ cytosine arabinoside $100 \mathrm{mg} / \mathrm{m}^{2} /$ day on days $1-5$, i.v. and $P=$ prednisolone $30 \mathrm{mg} / \mathrm{m}^{2} /$ day on days $1-5$, p.o ) (Spiers, 1972). In view of the probable leukaemic involvement of his hypothalamus, external radiotherapy was given to the hypothalamic area. Hyperuricaemia was satisfactorily controlled with allopurinol. This therapy produced a fall in the circulating blast cell count, but with the concomitant neutropenia the patient developed two episodes of pyrexia. The first of these responded well to antibiotic therapy (Tattersall et al., 1972), no cause for the pyrexia being found. The second episode was associated with a perianal abscess and $E$. coli septicaemia, and responded well to surgical drainage and antibiotics. Subsequently the patient developed pulmonary oedema possibly on the basis of leukaemic infiltration of his myocardium. Therapy was unsuccessful and the patient died on January 10, 1973. Permission for necropsy was refused on religious grounds.

\section{Discussion}

Unfortunately, without necroscopy the presumptive aetiology of the diabetes insipidus in this case could not be substantiated. However, in cases previously described in the literature (Castaigne and Hubault, 1953; Eilersen, 1960; Fabiani and Lucentini, 1955; Flynn and Bowers, 1947; Joseph and Levin, 1956; Laakso, 1964; Malter, Gross and Teree, 1969; Miller and Campbell, 1971; Rossenzweig and Kendall, 1966; Camarri and Fantoria, 1972) both leukaemic deposits (Cammari and Fantoria, 1972) and haemorrhage (Rosenzweig and Kendall, 1966) have been found in the region of the hypothalamus. Haemorrhagic lesions have usually been associated with low platelet counts at presentation (Laakso, 1964; Rosenzweig and Kendall, 1966) which would 
suggest that in this patient who was not thrombocytopenic, the hypothalamic lesion was a deposit. In previously reported cases, diabetes insipidus has been described as a presenting symptom (Joseph and Levin, 1956) and also has occurred during the course of the disease (Laakso, 1964). Most cases have been adults who have all had acute leukaemia and there are a few reports of children having diabetes insipidus as a complication of acute lymphoblastic (Malter $e t$ al., 1969) or acute myeloblastic leukaemia (Joseph and Levin, 1956).

No cases found in the literature had a markedly raised $\mathrm{Hb} \mathrm{F}$ and it seems likely from our studies that this was a consequence of his leukaemia.

\section{References}

Camarri, E. \& Fanteria, E. (1972) Diabetes insipida en el curso de una leucemia aguda. Interpretacion patogenetica. Sangre (Barc), 17, 3, 401.

Castaigne, P. \& Hubault, A. (1953) Diabète Insipide et leucémic. Revue du Practicien, 3, 1871.

EILERSEN, P. (1960) Diabetes insipidus presenting as leukosis. Ugeskrift for Laeger, 122, 1249.

Fabiani, F. \& LuCENTINi, L. (1955) Case of acute hemocytoblastic leukaemia beginning and ending with the complicating disease of diabetes insipidus. Progressive Medicine, 11, 269.
FlynN, J.E. \& Bowers, J.M. (1947) Acute lymphatic leukaemia with diabetes insipidus and uraemia. Journal of Urology, 58, 106.

Hall, R., Ormston, B.J., Besser, G.M., Cryer, R.J. \& McKENDRICK, M. (1972) The thyrotrophin releasing hormone test in diseases of the pituitary and hypothalmus. Lancet, i, 759.

JoSEPH, M.C. \& LEvin, S.E. (1956) Leukaemia and diabetes insipidus: case report with unexpected effect of cortisone. British Medical Journal, 1, 1328.

LAakso, W.B. (1964) Diabetes insipidus secondary to acute leukaemia: a case report. American Journal of Medical Science, 247, 451.

Malter, I.J., Gross, S. \& Teree, T.M. (1969) Diabetes insipidus complicating acute lymphocytic leukaemia. American Journal of Diseases of Children, 117, 228.

Miller, V.I. \& Campbell, W.G. (1971) Diabetes insipidus as a complication of leukaemia. Cancer, 28, 666.

Rosenzweig, M.D. \& Kendall, J.M. (1966) Diabetes insipidus as a complication of acute leukaemia. Archives of Internal Medicine, 117, 397.

SPIERS, A.S.D. (1972) Chemotherapy of acute leukaemia. Clinics in Haematology, 1, 127.

Tattersall, M.H.N., SPiers, A.S.D. \& Darrell, J.H. (1972) Initial therapy with combination of five antibiotics in febrile patients with leukaemia and neutropenia. Lancet, i, 162.

White, J.M. (1972) In: Haematology (Ed. by A. V. Hoffbrand and S. M. Lewis), p. 214.

\section{Megaloblastic anaemia associated with the oral contraceptive pill}

\author{
Michael M. Meguid \\ M.B., B.S.
}

\author{
WALTER Y. LOEBL \\ M.R.C.P.
}

Bethnal Green Hospital, London, E.C.3

\begin{abstract}
Summary
A 27-year-old housewife suffered from severe headaches for a period of 2 years which developed after she started taking an oral contraceptive pill. During this time she gradually developed folic acid deficiency anaemia. This resulted from the inhibition by 'the pill' of the intestinal conjugase system required to deconjugate polyglutamic folate. The patient's headache did not recur after stopping the pill and her anaemia improved with folic acid supplement. The relation between folic acid metabolism and 'the pill' is discussed.
\end{abstract}

Correspondence: Dr M. M. Meguid, Department of Surgery, Harvard Medical School at Peter Bent Brigham Hospital, Boston, Massachusetts 02115, U.S.A.
Megaloblastic anaemia associated with oral contraception

A large number of metabolic side effects induced by the contraceptive pill have been described (Drill, 1965). Shojania, Hornady and Barnes (1968), Snyder and Necheles (1969) and Streiff (1970) have described lowered levels of serum folate in women on oral contraceptives, but overt megaloblastic anaemia appears to be uncommon. The following report describes this entirely remediable condition which presented in an insidious form.

\section{Case report}

Mrs M.K., aged 27 years, was seen in the casualty department. She had taken 16 tablets of codeine 